\title{
Setting the Stage-Agency Support for Restoring Corridors
}

\author{
Gregory E. Eckert
}

A s many readers of Ecological Restoration are aware, work is underway in Washington State to remove 2 dams on the Elwha River. For almost 100 years, the dams blocked movement of 5 species of Pacific salmon (Oncorhynchus spp.), as well as nutrients from upland forests to coastal ecosystems (Olympic National Park 2012). Elsewhere natural resource managers are working to restore ecological corridors on the landscape. By corridor, I include specific pieces of infrastructure, such as fencing and culverts, linear habitat features, and broad ecosystem attributes that facilitate the natural movement of a species across its range. For example, in California's Santa Monica Mountains, a complex mix of public and private lands, National Park Service scientists work with state transportation managers to couple highway infrastructure projects with monitoring and research to understand which, and under which conditions, highway improvements are effective in facilitating wildlife movement across roads (Strasburg 2006). In 2008, the U.S. Forest Service (USFS) established the nation's first designated wildlife migration corridor to allow for the annual $241-\mathrm{km}$ movement of pronghorn antelope (Antilocapra americana) in western Wyoming (Environmental News Service 2008). Managers continue to respond to a variety of laws and regulations directing them to conserve species and natural systems, but in these and other cases, they are applying their analysis and work at larger scales and in a landscape ecology context. This is a result of a combination of factors, including developments in conservation biology, restoration ecology, and landscape ecology; increasing ecological pressures (contamination, biological invasions, anthropogenic climate change, habitat loss, fragmentation, etc.); and a stark realization that our protected area boundaries rarely reflect the needs of biological and ecological resources and processes. Common across these actions is a significant investment in partnering and cooperation and in research of restoration techniques and connectivity effectiveness before, during, and after implementation. Federal and state agencies are working to facilitate the former, while articles in this special edition of Ecological Restoration address the latter; that is, provision of more tools to increase efficiencies and effectiveness in the emerging area of corridor restoration.
As identified above, one area that requires more attention to implement corridor restoration is to collaborate among the myriad partners on the landscape-federal, state, conservation and recreational organizations, and private landowners. Federal and state agency landscape initiatives are underway to increase cooperation among resource management organizations while continuing to respect individual jurisdictions and missions and to seek compatibility with other uses of the landscape. Through these initiatives, restoration practitioners can better identify partners with whom to develop and implement their work. Because much restoration work is still at the local site scale, these partnerships also enable better integration and interpretation of results at broader scales. These initiatives include the following:

- In its October 2010 Progress Report, The Council on Environmental Quality-sponsored Interagency Climate Change Adaptation Task Force called for collaborative approaches within the federal and state agencies to address key, cross-cutting issues related to climate change adaptation. One product of this work is the draft National Fish, Wildlife, and Plants Climate Adaptation Strategy (National Fish, Wildlife, and Plants Climate Adaptation Partnership 2012), which is slated for publication in the Federal Register in September 2012. This strategy addresses species conservation across 8 major ecosystem types and recommends effective steps that should be initiated over the coming 5-10 years. Restoring connectivity among protected areas is a key component of the Strategy's goal to conserve habitat.

- Through its Wildlife Corridors Initiative, the Western Governors Association (WGA) created the WGA Wildlife Council, which is directing the development of information sources and coordination of wildlife corridor conservation. One of these products is the Crucial Habitat Assessment Tool, an online system that provides information on key habitat and corridors for wildlife at state and regional scales. Use of this tool supports corridor identification and conservation planning (Western Governors' Wildlife Council 2012).

- Landscape Conservation Cooperatives (LCCs) were established by Department of Interior Secretary Ken Salazar in 2009 (U.S. Department of Interior 2009). 
These cooperatives establish the foundation for a network of public-private partnerships to protect natural resources. Specifically, the LCCs have been challenged to identify best practices, connect efforts, and identify information and conservation gaps through information sharing and conservation design.

- An "All Lands" approach was established by Secretary of Agriculture Tom Vilsack as a broad vision for a restoration-focused approach to managing the nation's forests, including state and private lands. This approach is being built into the USFS's Planning Rule implementation and is reflected in its Forest Landscape Restoration Program (Tidwell 2010).

- The Interagency Joint Fire Science Program has supported the development of a community of practice among researchers and practitioners, through its regional consortia to promote information dissemination and adoption for fire science, with movement towards addressing a broader range of natural resource science and management issues (Joint Fire Science Program 2010).

- Congress has supported landscape approaches to natural resource management through passage of laws, such as the Collaborative Forest Landscape Restoration Program (Omnibus Public Land Management Act, 2009, Title IV) and invasive species management (Consolidated Natural Resources Act, 2008).

These initiatives reflect the need to implement conservation strategies across traditional geographic and governance lines. This begins with cooperation among managers through networks that can be based on conservation areas, organizations and/or information (Robles et al. 2007). However, the physical disconnect between habitat patches and the need to connect quality habitat at the ecological landscape scale are increasing concerns. Strategies then shift to protect large areas that provide broader habitat ranges and/or redundancy of habitats that are accessible to species for seasonal or annual movements, or for anticipated range shifts due to alterations of the species climate envelope. Protecting and restoring large areas can be prohibitive, but managers can seek to work with partners to increase, through restoration, the permeability or connectedness among conservation areas. In a review of strategies in response to climate change impacts, Heller and Zavaleta (2009) identified improvements of landscape connectivity as the most frequent recommendation for conservation managers. The authors include options to enhance connectivity in several forms, including expanding protected areas, conducting conservation work along existing corridors, such as rivers, rail lines, and shelterbelts in agricultural systems, and promoting matrix management (Heller and Zavaleta 2009). These recommendations are part of a continuum of actions that are directed to conserve species as anthropogenic and rapid climate change further restrict or degrade existing habitats.

However, managers continue to need evidence-based support, including corridor oriented research syntheses, frameworks for science application, and practices that are appropriate to the scale of the species, ecosystem, or protected area. Articles in this issue address a range of these needs. For example, the needs of wildlife managers and partners, such as Highway Departments or urban greenway managers, will vary. The work resulting from the ARC competition identifies this need in terms of flexible design approaches. Beier's work on framing corridors in the context of climate change identifies guidance on restoration strategies and relates these to the scale of projects. For example, small projects contribute to short distance movements while coarse scale process restoration, such as fire, can contribute to landscape attributes for migrations. The analysis of Ryan and Hartter examines public resource management within a socio-ecological rubric, and Gunson's analysis of signage helps us understand the role that the public can play in our connectivity efforts. Evans and colleagues remind us that we must develop a keen understanding of the natural history of the focal species for corridor design. These and other articles add to the momentum that is building among professional and non-government organizations. For example, The Wildlife Conservation Society published a practical guide to address ecological connectivity (Aune et al. 2011), and the Wildlands Network and the Society for Ecological Restoration are developing tools based on their joint workshop on the role of ecological restoration in continental-scale conservation efforts. Reports in this issue reflect, and hopefully will encourage, additional collaboration among agency managers and scientists along with conservation organizations, consultant practitioners, and academics.

\section{References}

Aune, K., P.Beier, J. Hilty and F. Shilling. 2011. Assessment and Planning for Ecological Connectivity: A Practical Guide. The Wildlife Conservation Society, New York, NY.

Consolidated Natural Resources Act. 2008. 16 USC 1122 Stat. 754. PL110-229.

Environmental News Service. 2008. Ancient pronghorn path becomes first U.S. wildlife migration corridor. www .ens-newswire.com/ens/jun2008/2008-06-17-091.asp.

Heller, N.E. and E.S. Zavaleta. 2009. Biodiversity management in the face of climate change: A review of 22 years of recommendations. Biological Conservation 142:14-32.

Joint Fire Science Program. 2010. Regional Consortia: Connect to Local Experts. www.firescience.gov/JFSP_consortia.cfm.

National Fish, Wildlife, and Plants Climate Adaptation Partnership. 2012. National Fish, Wildlife and Plants Climate Adaptation Strategy. Association of Fish and Wildlife Agencies, Council on Environmental Quality, Great Lakes Indian Fish and Wildlife Commission, National Oceanic and Atmospheric Administration, and U.S. Fish and Wildlife 
Service. Washington, DC. www.wildlifeadaptationstrategy .gov/public-review-draft.php.

Olympic National Park. 2012. Elwah River Restoration. Brochure. National Park Service. www.nps.gov/olym/ naturescience/upload/ElwhaRiverRestorationBrochure_ 2012-3.pdf.

Omnibus Public Land Management Act. 2009. www.govtrack.us/ congress/bills/111/hr146.

Robles, M.D., G.E. Eckert, L. Mehrhoff and M. Klein. 2007. Southeast Seamless Network of Protected Areas: Partnership Opportunities in Biodiversity Conservation, Invasive Species Management and Recreation. NatureServe, Arlington, Virginia.

Strasburg, J.L. 2006. Roads and genetic connectivity. Nature $440: 875-876$.
Tidwell, T. 2010. An All-Lands Approach to Conservation. Speech given to the Western States Land Commissioners Associations, Winter 2010 Conference, Little Rock, AR. U.S. Department of Interior. 2010. Addressing the Impacts of Climate Change on America's Water, Land, and Other Natural and Cultural Resources. Secretarial Order Number 3289, Amendment No. 1, February 22, 2010.

Western Governor's Association. 2012. Initiative on wildlife corridors and crucial habitat. www.westgov.org/wildlife.

Gregory E. Eckert, PhD, Restoration Ecologist, National Park Service, 1201 Oakridge Drive, Fort Collins, CO 80525, greg eckert@nps.gov. 